\title{
Screening Data Reveals that Spirogyra triplicata, a Fresh Water Algae Induces Robust Anti-Proliferative Activity Against A549 Cells
}

\author{
Ankita Mridha, Priya K Gopal, Santanu Paul*
}

Ankita Mridha, Priya K Gopal, Santanu Paul*

Laboratory of Cell and Molecular Biology, Department of Botany, University Of

Calcutta, 35 Ballygunge Circular Road Kolkata, West Bengal 700019, INDIA.

\section{Correspondence}

\section{Santanu Paul}

Laboratory of Cell and Molecular Biology, Department of Botany, University Of Calcutta, 35 Ballygunge Circular Road, Kolkata, West Bengal 700019, INDIA.

Phone no: +919874192648

E-mail: spaul_1971@yahoo.com

History

- Submission Date: 20-01-2020;

- Review completed: 12-02-2020;

- Accepted Date: 02-03-2020

DOI : 10.5530/pj.2020.12.86

Article Available online

http://www.phcogj.com/v12/i3

\section{Copyright}

(c) 2020 Phcogi.Com. This is an openaccess article distributed under the terms of the Creative Commons Attribution 4.0 International license.

\begin{abstract}
Introduction: Algae comprise a promising source of novel components with potent therapeutic agents. In particular, algae have been considered as a potential source of new bioactive compounds. The antioxidant data of our previous study with six different algal methanolic extract reveals the presence of high antioxidant, total phenol content and total flavonoid content in Spirogyra triplicata. Thus, we further focused on screening the anti-proliferative activity of six different green algae on five different cancer cell lines like MCF7, A549, HEPG2, REH, MOLT4. Methods: To fulfill our aim we performed MTT assay for testing anti-proliferative activity and DAPI staining for observing nuclear morphology. We also looked into the metabolomic profiling of Spirogyra triplicata by GC-MS chemometric study. Results: The result indicates that after 24 hours of treatment with methanolic extract of Spirogyra triplicata A549 was the most sensitive cell line with $\mathrm{IC}_{50}$ value of $24.07 \pm 1.09 \mu \mathrm{g} / \mathrm{ml}$. Followed by Rhizoclonium fontinale and Hydrodictyon reticulatum with $\mathrm{IC}_{50}$ value of $25.97 \pm 1.94 \mu \mathrm{g} / \mathrm{ml}$ and $32.50 \pm 1.97 \mu \mathrm{g} / \mathrm{ml}$ respectively. The HEPG2 cell line was the second most sensitive cell line against $S$. triplicata with $I C_{50}$ value of $30.20 \pm 1.45 \mu \mathrm{g} / \mathrm{ml}$. The MOLT4 cell line was detected as most resistant cell line against the green algal extract in this study. Though the methanolic extracts of six green algae showed maximum to moderate anti-proliferative activity on different cancer cell line but no significantly affect on normal PBMC was observed. Nuclear fragmentation was observed in a dose dependent fashion by DAPI staining on A549 cells treated with methanolic extract of Spirogyra triplicata. We further looked into the chemo profiling of Spirogyra triplicata by GCMS analysis. The result of GC-MS clearly indicates presence of nineteen major components and twenty-three minor components which have more or less bioactivity and would help in therapeutics in future. Conclusions: In brief this study indicates for the first time that green algae Spirogyra triplicata induces anti-proliferative activity specifically against A549 cell but not in normal PBMC. It can be concluded that Spirogyra triplicata holds a great promise as a good repository of anti cancer compounds which may be used in future drug discovery.
\end{abstract}

Key words: Spirogyra triplicata, Anti-proliferative, A549, GCMS.

\section{INTRODUCTION}

Cancer is a major health problem characterized by uncontrolled cell proliferation and its propagation. ${ }^{1}$ Statistical report of GLOBOCAN reveals that 18.1 million new cancer cases evolved within which 9.6 million cancer deaths eventuated in 2018 worldwide. ${ }^{2}$ Cancer treatment follows chemotherapy using cytotoxic drugs, radiation therapy and surgery. ${ }^{3}$ Though all these procedure have been reported to combat this dreaded disease, people still suffers with undesirable side effects. ${ }^{4}$ The use of plant-based bio-products for cancer treatment is rapidly growing in medical practices. ${ }^{5}$ Thus our vision was to hunt more natural sources for the treatment of cancer with minimum side effects. Scientists worldwide are engaged in designing the targeted therapies that can exterminate cancer cells without harming normal one. Natural products like algae, ${ }^{6}$ angeosperms, ${ }^{7-9}$ lichens,${ }^{10}$ Mashroom ${ }^{11}$ have been a continuous source of medicines to treat diseases and injury. Epidemiological studies proclaimed that the people of Asian countries who consumes high amount of fish and seafood have low incidence of particular type of cancers such as lung, breast, colorectal and prostate cancers. ${ }^{12}$ Reports consider algae as a repository of promising novel phytochemical as a source of biomedicine. ${ }^{13}$ Such therapies primarily try to understand how and by what mean cancer cells are different from normal non-transformed cells. It is explicit that cancer cells and normal cells are morphologically and behaviorally different. Current information suggests that bioactive components extracted from algae, as well as methyl jasmonate (a natural compound derived from the plant of jasmonates family), seem to have anti-cancer activities through multiple mechanisms of action, including downregulation of cancer-cell proliferation and metastasis, and through the promotion of apoptosis of cancerous cells. ${ }^{14}$ Many algae are still untouched to unmask. After getting positive results in antioxidant activity of some green algae, our focus was to check the antiproliferative activities of six green algae in human cancer and metabolomic studies of the most potent 
green methanolic algal extract. The result of which could be a great source of future medical discovery.

\section{MATERIALS AND METHODS}

Sample collection, identification and extraction
procedure

Green algae were collected from several lentic and slowly lotic sources of India. The collected samples viz. Rhizoclonium crassipellitum (RC), Spirogyra triplicata (ST), Pithophora cleveana (PC), Rhizoclonium fontinale (RF), Cladophoraglomerata (CG) Hydrodictyon reticulatum (HR) were identified by phycology specialist and voucher specimens deposited at Phycology lab, Botany Dept, University of Calcutta. The collected materials were processed and extracted according to our previous study. ${ }^{13}$

\section{Cell and cell culture reagents and chemicals}

MCF7, A549, HEPG2, REH, MOLT4 cell lines were kindly gifted from Dr. Sanjit Dey department of Physiology University of Calcutta and Mitali Chatterjee IPGMER, Kolkata. Cell lines were cultured at $1 \times 10^{6}$ cells $/ \mathrm{ml}$ in RPMI 1640 (Sigma Aldrich) or Dulbecco's Modified Eagle's medium (DMEM) (Sigma Aldrich) depending upon cell line, supplemented with $10 \%(\mathrm{v} / \mathrm{v}$ ) heat-inactivated FBS (Invitrogen), $2 \mathrm{mM}$ L-glutamine, $10 \mathrm{U} / \mathrm{ml}$ penicillin and streptomycin (Sigma Aldrich) and maintained in humidified 5\% $\mathrm{CO}_{2}$ incubator (HF-90). Percoll (Sigma aldrich), glutamine (Sigma aldrich), gentamicin (Sigma aldrich), Trypan blue (Sigma aldrich), MTT 3-(4,5 dimethylthiazol-2-yl)2,5-diphenyltetrazolium bromide (Sigma Aldrich), DAPI and PI for microscopic analysis of nuclear fragmentation were purchased from Sigma-Aldrich.

\section{Isolation of peripheral blood mononuclear cells (PBMC)}

Peripheral blood mononuclear cells constitute the cellular part of the blood containing all blood cells with a round nucleus. PBMCs are mainly invading cells that comprised of monocytes, $\mathrm{T}$ cells, B cells, natural killer (NK) cells, and dendritic cells. Peripheral blood mononuclear cells (PBMC) were isolated from heparinized venous blood of healthy normal volunteers by percoll density (Sigma aldrich) gradient centrifugation $(\mathrm{d}=1.082 \mathrm{~g} / \mathrm{L})$ creating prominent layers containing specific cell populations. The cells can then be isolated by extracting the respective layer. The total cell number and the number of viable cells were determined with Trypan blue (Sigma aldrich) exclusion. PBMC were then recovered at the interface and the retrieved cells were washed and re-suspended in phosphate-buffered saline (PBS) and finally fixed in RPMI 1640 (Sigma aldrich) supplemented with $2 \mathrm{mM}$ glutamine(Sigma aldrich), gentamicin (Sigma aldrich) and $10 \%$ heat inactivated FBS (invitrogen). ${ }^{15}$

\section{Cell viability assay}

To check the viability of cells after treating with methanol extracts, we performed the cell viability assay. Cells were harvested 96-well plate with increasing concentrations of STME and observed at 24 Hours of time point by MTT assay. ${ }^{16}$ In brief cells were incubated in triplicata in a 96-well plate at different concentrations of methanolic algal extract in a final volume of $200 \mu \mathrm{l}$ for $24 \mathrm{hrs}$ at $37^{\circ} \mathrm{C}$. Three hours before the completion of time points, $20 \mu \mathrm{l}$ of MTT solution $(5 \mathrm{mg} / \mathrm{mL})$ was added to each well. Formazone crystals formed, representing percentage of cell viability was assessed at $560 \mathrm{~nm}$. Cell apoptosis (100\%) was obtained by lysis of cells in 5\% SDS lysis buffer. All treatments were performed in triplicata. The percentage of cell viability was calculated as mentioned below:

$\%$ cell viability $=100^{*}$ (O.D. sample-O.D. $100 \%$ lysis $) /($ O.D. $0 \%$ lysisO.D.100\%lysis)

\section{Nuclear staining with DAPI}

Nuclear fragmentation is an important phenomenon of apoptosis and can be visualize by DAPI staining. ${ }^{17}$ Cells were seeded in 12 well plate and treated with STME at different concentrations for $24 \mathrm{~h}$. After treatment, cells were collected, washed with $1 \mathrm{X}$ phosphate buffered saline (PBS). DAPI ( $1 \mu \mathrm{g} / \mathrm{mL}$ in PBS) was added and incubated for 15 $\mathrm{min}$ at room temperature. The stained cells were observed under a fluorescence microscope.

\section{Microscopic staining of apoptotic cells by PI}

Based on our MTT data, we found that A549 cell lines are mostly affected by Spirogyra triplicata. Thus we took control and three increasing concentration of STME treated A549 cell well plate. The treated $1 \times 10^{5}$ A549 cells were stained with freshly prepared PI $(1 \mu \mathrm{g} / \mathrm{ml})$ and incubated for $10 \mathrm{~min}$. after washing, the cells were visualized under fluorescence microscope. ${ }^{18}$ (Dewinter).

\section{Metabolomic study by GCMS Study}

From our previous study, after getting positive antioxidant result and high amount of total phenol and flavonoid content, our next aim was to analyze the chemometric activity by GC-MS study.

\section{Sample preparation for GC/MS analysis}

The 10mg algal methanol extract was dissolved in $1 \mathrm{ml}$ of the HPLC grade methanol, vortexed properly for well mixing and finally filtered through $0.22 \mu \mathrm{m}$ syringe filter (Millipore Corp., Bedford, MA, USA).

\section{Instrumentation and chromatographic conditions}

Agilent Technologies 7890A GC System liquid autosampler was used for GC/MS analysis. The gas chromatograph was interfaced to a mass spectrometer instrument utilizing the following conditions viz. HP-5 ms column $(30 \mathrm{~m} \times 0.25 \mathrm{~mm} \times 0.25 \mu \mathrm{m})$, fitted with silica and coupled to an Agilent triple quadrupole Mass selective Detector MSD7000, ionization voltage $70 \mathrm{eV}$; electron multiplier energy 2000 $\mathrm{V}$; transfer line temperature, $295^{\circ} \mathrm{C}$. Helium as carrier gas $(1 \mathrm{ml} / \mathrm{min})$. The in:tial temperature was $60^{\circ} \mathrm{C}$ for $0 \mathrm{~min}$, then gradually increased to $320 \mathrm{C}$ automitically and in the split ratio mode (10:1), transfer line temperature 295 C. ${ }^{19}$

\section{Identification of components}

NIST MS search program v.2.2 (NIST 11) [National Institute Standard and Technology] was utilized for the interpretation GC/MS mass spectrum. Finally, name, molecular weight and structure of the components of the test material were determined.

\section{Statistical analysis}

The results were expressed as mean \pm standard deviation. Descriptive statistics was used to analyze the mean, standard deviation, variation, and level of statistical significance between groups. When $p<0.05$ and $p<0.01$, it was considered statistically significant for analysis of percent inhibition of cell growth.

\section{RESULTS}

\section{Differential anti-proliferative activity of algal extract by MTT assay}

To fish out the most potent anti-cancerous extract, we investigated the anti-proliferative effects of six different green algal methanolic fraction and tested on five different cancer cell lines e.g. MCF-7, A549, HEPG2, REH, MOLT4. Each cell line was treated with six different algal extract for 24hour time points followed by MTT assay. Results of the MTT assay proved that A549 was the most sensetive cell line 
which was significantly down-regulated by most of the green algae (Table 1). The most remarkable result was shown by Spirogyra triplicata methanol extract (STME) having maximum anti-proliferative activity against A549 cell line with $\mathrm{IC}_{50}$ value of $24.07 \pm 1.09 \mu \mathrm{g} / \mathrm{ml}$. Followed by Rhizoclonium frontinale against A549 cell line, Spirogyra triplicata against HEPG2 cell line and Rhizoclonium frontinale against HEPG2 cell line with $\mathrm{IC}_{50}$ value of $25.97 \pm 1.94 \mu \mathrm{g} / \mathrm{ml}, 30.2 \pm 1.45 \mu \mathrm{g} / \mathrm{ml}$ and $30.45 \pm$ $2.67 \mu \mathrm{g} / \mathrm{ml}$ respectively. The anti-proliferative activity of A549 cell line mostly by Hydrodictyon reticulatum, Rhizoclonium crassipellitum and Pithophora cleveana methanolic extract with $\mathrm{IC}_{50}$ values of $32.50 \pm 1.35$ $\mu \mathrm{g} / \mathrm{ml}, 34.71 \pm 1.79 \mu \mathrm{g} / \mathrm{ml}$ and $37.54 \pm 1.47 \mu \mathrm{g} / \mathrm{ml}$ respectively. STME shows moderate anti-proliferative activity against MCF-7 cell line with $\mathrm{IC}_{50}$ value $47.28 \pm 1.98 \mu \mathrm{g} / \mathrm{ml}$ but against $\mathrm{REH}$ and Molt 4 cell lines did not show significant anti-proliferative activity having $\mathrm{IC}_{50}$ values of $82.68 \pm 2.38$ and $89.71 \pm 1.82$ respectively (Figure $1 b$ ) . Rhizoclonium frontinale (RFME) also exhibited lower anti-proliferative activity against REH, and MOLT4 cells (Figure 1d). From the Figure 1 we can conclude that cancer cell viability decreased with the dose dependent fashion. However, anti-proliferative activity of Cladophora glomerata, Pithophora cleveana, Rhizoclonium crassipellitum, Hydrodictyon reticulatum were found to be of least anti-proliferative efficacies against MOLT4 cell line with $\mathrm{IC}_{50}$ values of $72.82 \pm 1.3 \mu \mathrm{g} / \mathrm{ml}, 202.8 \pm 1.89 \mu \mathrm{g} /$ $\mathrm{ml}, 213.7 \pm 2.83 \mu \mathrm{g} / \mathrm{ml}, 165.9 \pm 1.34 \mu \mathrm{g} / \mathrm{ml}$ respectively (Table 1 ). Thus it is proved from the data that MOLT4 cells were most resistant (Table 1) to all the extracts tested. In a nutshell from the MTT assay results we observe that $S$. triplicata possesses most promising Anti-cancer potentiality followed by $R$. frontinale (Figure 1d) in A549 cells. Whereas no significant anti proliferative effect was observed in normal PBMC isolated from healthy donor.

Table 1. $I C_{50}$ values of six different green algal extract on different cell lines.

\begin{tabular}{cccccc}
\hline \multicolumn{7}{c}{ Algae } & MCF-7 & A549 & HEPG2 & REH & MOLT4 \\
\hline $\begin{array}{c}\text { Rhizoclonium } \\
\text { crassipellitum } \\
\quad \text { Spirogyra }\end{array}$ & $42.35 \pm 1.3$ & $34.71 \pm 1.79$ & $37.63 \pm 1.82$ & $136.2 \pm 1.26$ & $381.3 \pm 1.9$ \\
$\begin{array}{c}\text { triplicata } \\
\text { Pithophora } \\
\text { cleveana }\end{array}$ & $47.28 \pm 1.98$ & $24.07 \pm 1.09$ & $30.20 \pm 1.45$ & $82.68 \pm 2.38$ & $89.71 \pm 1.82$ \\
$\begin{array}{c}\text { Rhizoclonium } \\
\text { fontinale }\end{array}$ & $50.48 \pm 2.7$ & $37.54 \pm 1.47$ & $57.19 \pm 1.68$ & $82.29 \pm 1.37$ & $202.8 \pm 1.89$ \\
$\begin{array}{c}\text { Cladophora } \\
\text { glomerata }\end{array}$ & $70.24 \pm 1.96$ & $48.03 \pm 1.42$ & $39.07 \pm 1.38$ & $78.46 \pm 1.62$ & $72.82 \pm 1.3$ \\
$\begin{array}{c}\text { Hydrodictyon } \\
\text { reticulatum }\end{array}$ & $77 \pm 1.54$ & $32.50 \pm 1.97$ & $111 \pm 2.58$ & $62.04 \pm 1.39$ & $165.9 \pm 1.34$ \\
\hline
\end{tabular}

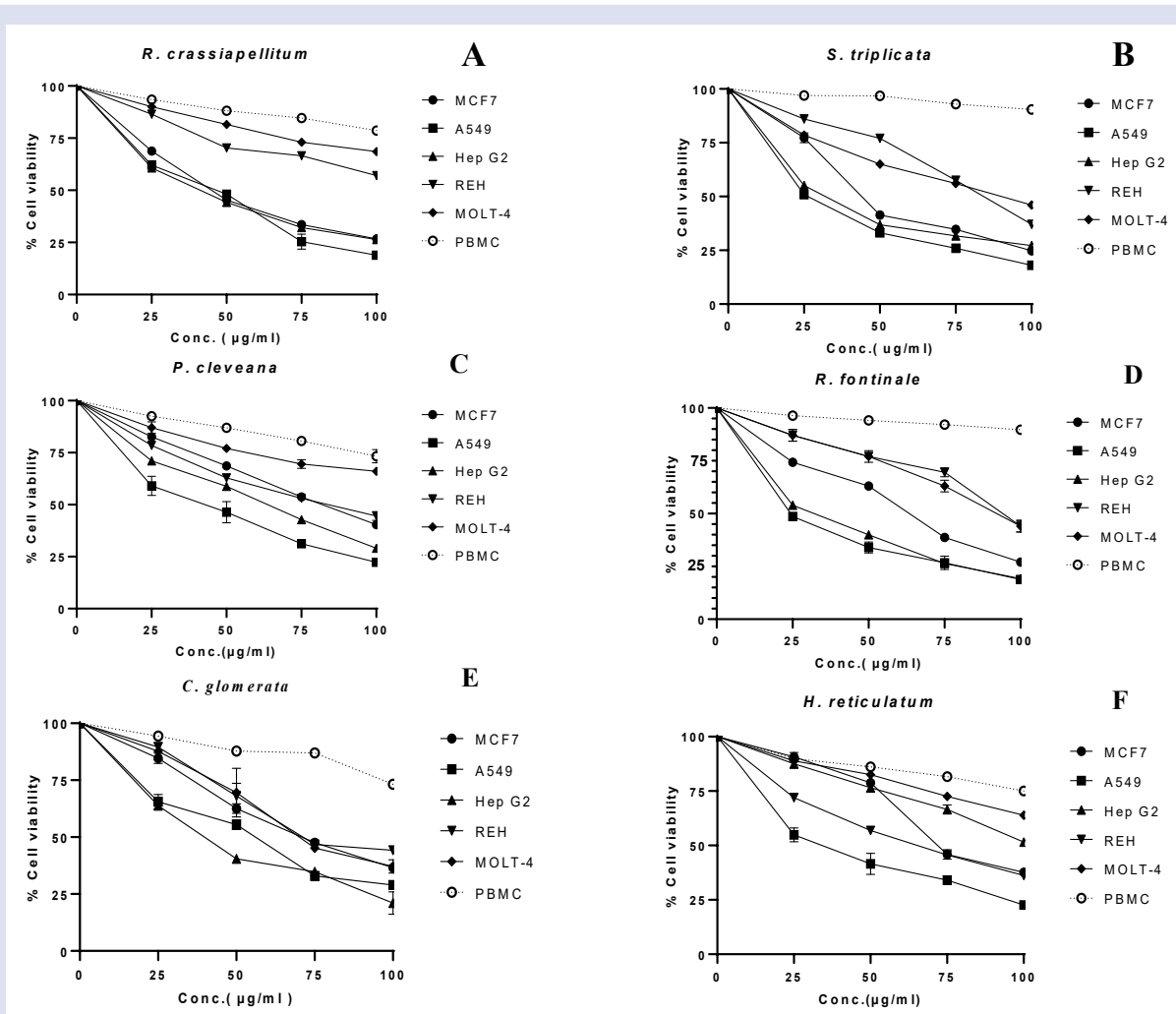

Figure 1: Effect of different algal extract on MCF7, A549, HEPG2, REH, MOLT4 Cell Lines and normal PBMC. Effect of six different algal methanolic extract (A-F), $(25 \mu \mathrm{g} / \mathrm{ml}-100 \mu \mathrm{g} / \mathrm{ml})$ as determined by MTT assay at $24 \mathrm{~h}$ time point. PBMC cells were unaffected but A549 cells are mostly affected. a-Rhizoclonium crassipellitum (RC), b-Spirogyra triplicata (ST), c- Pithophora cleveana (PC), d-Rhizoclonium fontinale (RF), e- Cladophora glomerata (CG), f- Hydrodictyon reticulatum (HR). 
Effects of S. triplicata methanolic extract on cellular morphological changes of A549 cells

As the methanolic extract of $S$. triplicata showed the most potential antiproliferative activity we further looked at the nuclear fragmentation of A549 cells upon treatment with $S$. triplicata. The characteristic nuclear fragmentation induced during apoptosis was measured using DAPI staining. DAPI is a nuclear stain that can be visualized under UV fluorescence when excited under fluorescence microscope. In our study, DAPI staining revealed the changes related with apoptosis in A549 cells treated with the methanolic fraction of S. triplicata. The morphological changes associated with apoptosis such as chromatin condensation, nuclear fragmentation, and margination of nucleus are evident in A549 cells upon treatment (Figure 2).

\section{Observation of A549 cells by PI staining}

PI is a membrane impermeant stain; it can't penetrate through the living cell membrane. When the cell undergoes apoptosis, the cell membrane becomes leaky and the stain can enter into the cell. PI staining can be used to exhibit the morphologic condition of DNA after treatment with methanolic extract. Thus to observe the amount of dead cells we performed the PI staining. In our study four groups of cells were considered in which first one untreated group i.e. no STME concentration was given to A549 cells and three ascending concentration of STME were given to rest three cell groups. In control cells presence of little amount of PI stained cells were visualized which suggests that there was no such apoptotic cells. As most of the cells were alive, PI did not get into the cells. Whereas the number of PI stained cells increased according to the increase in the concentration of STME treatment (Figure 3a). The figure clearly represents the scenario where the control cell with little PI stained cell, means most of the cells having, membrane integrity, thus PI stain was unable to enter into maximum cells. Whereas the increasing concentration of STME changes the cellular membrane integrity thus allowed to enter PI within the cell and looks red in colour under fluorescence microscope and \% cell death gradually increased (Figure 3b, 3c, 3d).

\section{Chemo profiling analysis by GC-MS}

Previous analysis with STME indicates higher percentages of antioxidant capacities as well as the total phenolic content and total flavonoid content. ${ }^{13}$ Henceforth, it was further investigated for metabolomic profiling by GC/MS analysis. GC/MS chemometric profiling of STME as per aforesaid experimental procedure showed numerous different peaks indicating the presence of diversified phyto chemotypes (Figure 4). The methanol extract of STME revealed the presence of different chemotypes which were characterized and identified by comparison of their mass fragmentation patterns with the similar compounds present in the NIST database. Of these nineteen different chemotypes, 1,4-Phosphasilacyclohexane, 4,4-dimethyl-1-phenyl- (27.33\%), Linoleic acid ethyl ester (8.57\%), (Z,Z,Z)-9,12,15-Octadecatrienoic acid (7.61\%), 9,12,15-Octadecatrienoic acid, methyl ester, (9Z,12Z,15Z)(6.33\%), Pentadecanoic acid, 13-methyl-, methyl ester (6.04\%), (Z,Z,Z)-9,12,15-Octadecatrienoic acid (4.98\%), 7,10.13-Eicosatrienoic acid, methyl ester (4.23\%), Neophytadiene(3.73\%), 1,2,3-Benzenetriol (3.49\%), Hexylene glycol(2.72\%), Doconexent(2.53\%), Azulene (2.53\%), 10,13-Eicosadienoic acid, methyl ester(2.32\%), Cyclopentanetridecanoic acid, methyl ester (1.99\%), Methyl octyl phthalate (1.48\%), 2-Pyrrolidinone, 1-methyl- (1.34\%), 3',8,8'-Trimethoxy-3-piperidyl-2,2'-binaphthalene-1,1',4,4'-tetrone (1.32\%), 6, 19-Cycloandrostane-3,7-diol, 3 $\beta$-methoxy- (1.26\%), Methyl tetradecanoate $(1.15 \%)$ were found to be the major constituents (Table 2a). Along with the nineteen major components, twenty-three minor
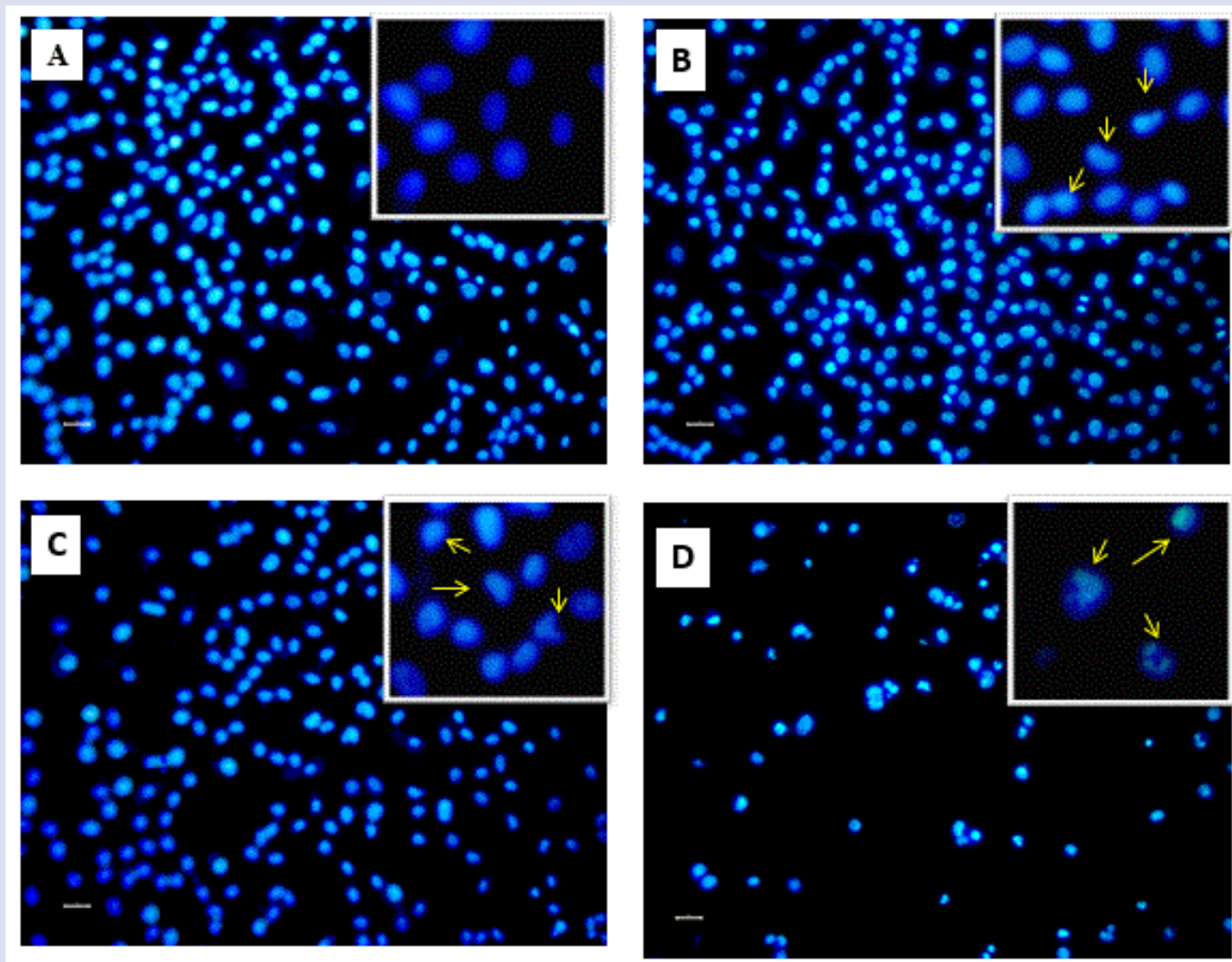

Figure 2: Detection of nuclear fragmentation in A549 cells by DAPI staining after algal extract treatment. For 24 hours. Cells show high degree of nuclear fragmentation in a concentration and time dependent manner under fluorescence microscope. 



Figure 3: PI staining under fluorescence microscope. A-Control cell no STME treatment, B-15 $\mu \mathrm{g} / \mathrm{ml}$ STME treatment, C- $24.07 \mu \mathrm{g} /$ $\mathrm{ml} \mathrm{STME}$ treatment, D- $40 \mathrm{\mu g} / \mathrm{ml}$ STME treatment.

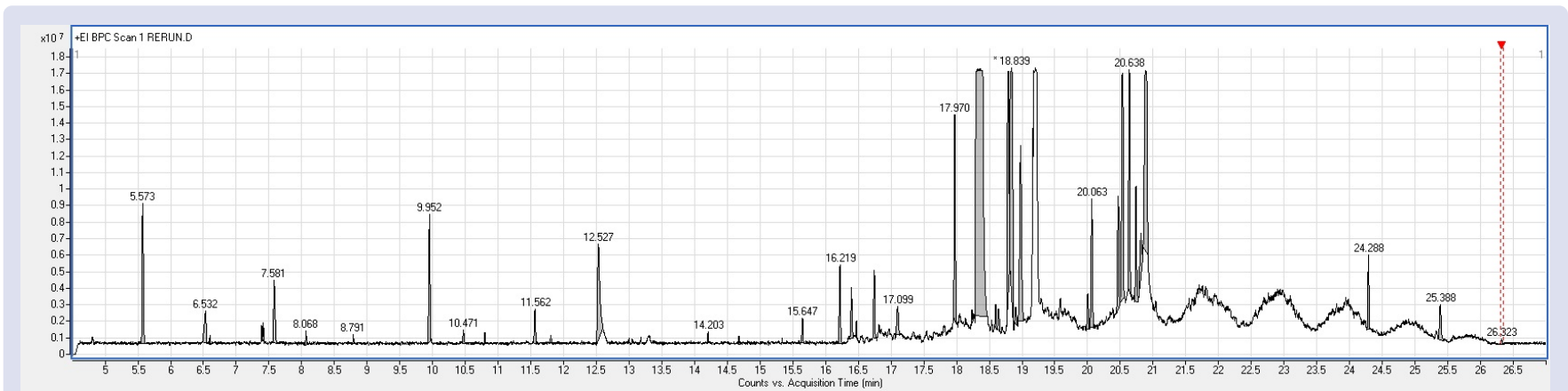

Figure 4: GC/MS chemometric profiling of STME.

components were detected in trace amount (Table 2b, Figure 2). These nineteen major components were further investigated for their biological efficacies and most of them have diverse range of positive pharmaceutical and therapeutic functions ${ }^{20-27}$ (Table 2). From the above study it can be concluded that the methanolic fraction of $S$. triplicata possesses a wide range of phytochemicals which holds a great promise for future drugs for combating cancer.

\section{DISCUSSION}

The use of naturally occurring plant-based products has shown promising results in the treatment of cancer. Due to the complexity of cancer, novel bioactive compounds with multi targeting efficacy are the need of the hour. In this paper we looked into the anti-proliferative effect of freshwater green algae Spirogyra triplicata by MTT assay. Previously we performed a pilot study with both Ethyl acetate and methanol extract of Spirogyra triplicata and our findings demonstrate that the methanolic fraction of $S$. triplicata possesses the most potent anticancer activity against human lung cancer cells (A549) and comparable activity in few other cancer cell lines. In contrast no significant cytotoxicity was observed in the normal PBMC cells. Next, we used DAPI, a fluorescent DNA-binding agent to visualize morphological changes of the nucleus. Nucleus gets fragmented with increase in concentration of the methanolic extracts. The GC/MS chemometric profiling is a useful technique to detect the volatile compounds present in natural products. The GC/MS fingerprinting of methanolic fraction of $S$. triplicata revealed the presence of nineteen major bioactive components in large amount along with twenty-three minor components in trace amount. The major phytochemical groups namely fatty acid esters, sterols, 
Table 2a: GC-MS chemo profiling of major component of Spirogyra triplicata methanolic extract.

\begin{tabular}{|c|c|c|c|c|c|c|c|c|c|}
\hline SI No & $\begin{array}{l}\text { Peak RT } \\
\text { (min) }\end{array}$ & Peak Area & $\begin{array}{c}\text { Peak } \\
\text { Area\% } \\
\end{array}$ & Compound Name & $\begin{array}{c}\text { Mol. } \\
\text { Formula }\end{array}$ & $\begin{array}{l}\text { Mol. Wt. } \\
(\mathrm{g} / \mathrm{mol})\end{array}$ & CAS No. & Chemotype & Activity \\
\hline 1 & 18.36 & 116361042 & 27.33 & $\begin{array}{l}\text { 1,4-Phosphasilacyclohexane, } \\
\text { 4,4-dimethyl-1-phenyl- }\end{array}$ & $\mathrm{C}_{12} \mathrm{H}_{19} \mathrm{PSi}$ & 222 & $111514-26-2$ & - & - \\
\hline 2 & 18.83 & 36485993 & 8.57 & Linoleic acid ethyl ester & $\mathrm{C}_{20} \mathrm{H}_{36} \mathrm{O}_{2}$ & 308.4986 & $544-35-4$ & $\begin{array}{l}\text { fatty acid ethyl } \\
\text { ester }\end{array}$ & $\begin{array}{l}\text { human metabolite and a } \\
\text { plant metabolite }{ }^{20}\end{array}$ \\
\hline 3 & 20.88 & 32403118 & 7.61 & $\begin{array}{c}(\mathrm{Z}, \mathrm{Z}, \mathrm{Z})-9,12,15- \\
\text { Octadecatrienoic acid }\end{array}$ & $\begin{array}{l}\mathrm{C}_{18} \mathrm{H}_{30} \mathrm{O}_{2} \\
\mathrm{C}_{18} \mathrm{H}_{30} \mathrm{O}_{2}\end{array}$ & 278.4 & $463-40-1$ & Fatty acid & - \\
\hline 4 & 20.53 & 26983285 & 6.33 & $\begin{array}{l}\text { 9,12,15-Octadecatrienoic } \\
\text { acid, methyl ester, } \\
(9 \mathrm{Z}, 12 \mathrm{Z}, 15 \mathrm{Z})-\end{array}$ & $\mathrm{C}_{19} \mathrm{H}_{32} \mathrm{O}_{2}$ & 292.5 & $301-00-8$ & $\begin{array}{l}\text { Fatty acid methyl } \\
\text { ester }\end{array}$ & - \\
\hline 5 & 18.79 & 25733184 & 6.04 & $\begin{array}{l}\text { Pentadecanoic acid, } \\
\text { 13-methyl-, methyl ester }\end{array}$ & $\mathrm{C}_{17} \mathrm{H}_{34} \mathrm{O}_{2}$ & 270.4507 & $5487-50-3$ & Fatty acid ester & - \\
\hline 6 & 18.98 & 21237407 & 4.98 & $\begin{array}{c}(\mathrm{Z}, \mathrm{Z}, \mathrm{Z})-9,12,15- \\
\text { Octadecatrienoic acid }\end{array}$ & $\mathrm{C}_{18} \mathrm{H}_{30} \mathrm{O}_{2}$ & & $463-40-1$ & Fatty acid & - \\
\hline 7 & 20.63 & 18029271 & 4.23 & $\begin{array}{c}\text { 7,10.13-Eicosatrienoic acid, } \\
\text { methyl ester }\end{array}$ & $\mathrm{C}_{21} \mathrm{H}_{36} \mathrm{O}_{2}$ & 320 & $30223-51-9$ & Fatty acid ester & - \\
\hline 8 & 17.97 & 15915194 & 3.73 & Neophytadiene & $\mathrm{C}_{20} \mathrm{H}_{38}$ & 278 & $504-96-1$ & sesquiterpenoids & $\begin{array}{l}\text { Antioxidant, analgesic, } \\
\text { antipyretic, anti- } \\
\text { inflammatory, } \\
\text { antimicrobial, } \\
\text { antidiabetic, anti- } \\
\text { inflammatory, } \\
\text { antiarthritic, and } \\
\text { anticancer activities }\end{array}$ \\
\hline 9 & 12.52 & 14860304 & 3.49 & 1,2,3-Benzenetriol & $\mathrm{C}_{6} \mathrm{H}_{6} \mathrm{O}_{3}$ & 126.11 & $87-66-1$ & & - \\
\hline 10 & 5.57 & 11582577 & 2.72 & Hexylene glycol & $\mathrm{C}_{6} \mathrm{H}_{14} \mathrm{O}_{2}$ & 118.1742 & $107-41-5$ & Glycol & $\begin{array}{l}\text { Coating industry, inert } \\
\text { ingredient in pesticide } \\
\text { formulation, automobile } \\
\text { industry, pharmaceutical } \\
\text { and agrochemical } \\
\text { industry }{ }^{22}\end{array}$ \\
\hline 11 & 20.06 & 10801913 & 2.53 & Doconexent & $\mathrm{C}_{22} \mathrm{H}_{32} \mathrm{O}_{2}$ & 328.4883 & $6217-54-5$ & $\begin{array}{l}\text { polyunsaturated } \\
\text { very long-chain } \\
\text { fatty acid }\end{array}$ & $\begin{array}{c}\text { Doconexent with } \\
\text { mixture of other oil } \\
\text { act as a supplement of } \\
\text { DHA(which have anti } \\
\text { inflammatory effect in } \\
\text { brain. })^{23}\end{array}$ \\
\hline 12 & 9.95 & 10797783 & 2.53 & Azulene & $\mathrm{C}_{10} \mathrm{H}_{8}$ & 128.1705 & $275-51-4$ & hydrocarbon & $\begin{array}{l}\text { It has a role as a plant } \\
\text { metabolite and a volatile } \\
\text { oil component }{ }^{24}\end{array}$ \\
\hline 13 & 20.46 & 9902887 & 2.32 & $\begin{array}{l}\text { 10,13-Eicosadienoic acid, } \\
\text { methyl ester }\end{array}$ & $\mathrm{C}_{21} \mathrm{H}_{38} \mathrm{O}_{2}$ & 322 & $30223-50-8$ & $\begin{array}{l}\text { Fatty acid methyl } \\
\text { ester }\end{array}$ & - \\
\hline 14 & 20.73 & 8494916 & 1.99 & $\begin{array}{l}\text { Cyclopentanetridecanoic } \\
\text { acid, methyl ester }\end{array}$ & $\mathrm{C}_{19} \mathrm{H}_{36} \mathrm{O}_{2}$ & 296 & $24828-61-3$ & $\begin{array}{l}\text { Fatty acid methyl } \\
\text { ester }\end{array}$ & - \\
\hline 15 & 16.21 & 6325633 & 1.48 & Methyl octyl phthalate & $\mathrm{C}_{17} \mathrm{H}_{24} \mathrm{O}_{4}$ & 292 & $91485-83-5$ & Diisononyl ester & Plasticizer $^{25}$ \\
\hline 16 & 7.58 & 5716847 & 1.34 & 2-Pyrrolidinone, 1-methyl- & $\mathrm{C}_{5} \mathrm{H}_{9} \mathrm{NO}$ & 99 & $872-50-4$ & & $\begin{array}{l}\text { used in the petrochemical } \\
\text { industry, and in the } \\
\text { manufacturing of various } \\
\text { compounds, including } \\
\text { pigments, cosmetics, } \\
\text { insecticides, herbicides, } \\
\text { and fungicides and } \\
\text { anticancer }{ }^{26,27}\end{array}$ \\
\hline 17 & 24.28 & 5621412 & 1.32 & $\begin{array}{c}\text { 3',8,8'-Trimethoxy-3- } \\
\text { piperidyl-2,2'-binaphthalene- } \\
\text { 1,1',4,4'-tetrone }\end{array}$ & $\mathrm{C}_{28} \mathrm{H}_{25} \mathrm{NO}_{7}$ & 487 & $127611-84-1$ & - & - \\
\hline 18 & 20.81 & 5368432 & 1.26 & $\begin{array}{l}\text { 6, 19-Cycloandrostane-3,7- } \\
\text { diol, } 3 \beta \text {-methoxy- }\end{array}$ & $\mathrm{C}_{20} \mathrm{H}_{32} \mathrm{O}_{3}$ & 320 & - & & \\
\hline 19 & 16.74 & 4916926 & 1.15 & Methyl tetradecanoate & $\mathrm{C}_{15} \mathrm{H}_{30} \mathrm{O}_{2}$ & 242 & $124-10-7$ & $\begin{array}{l}\text { fatty acid methyl } \\
\text { ester }\end{array}$ & $\begin{array}{l}\text { plant metabolite, a } \\
\text { flavouring agent and a } \\
\text { fragrance }{ }^{28}\end{array}$ \\
\hline
\end{tabular}


Table 2b: GC-MS chemoprofiling of minor component of Spirogyra triplicata methanolic extract.

\begin{tabular}{|c|c|c|c|c|c|c|c|c|}
\hline SI No & $\begin{array}{l}\text { PeakRT } \\
(\mathrm{min})\end{array}$ & Peak Area & Peak Area\% & Compound Name & $\begin{array}{l}\text { Mol. } \\
\text { Formula } \\
\end{array}$ & $\begin{array}{l}\text { Mol. Wt. } \\
(\mathrm{g} / \mathrm{mol})\end{array}$ & CAS No. & Chemotype \\
\hline 1 & 16.39 & 4216235 & 0.99 & 3-Hydroxydodecanoic acid & $\mathrm{C}_{12} \mathrm{H}_{24} \mathrm{O}_{3}$ & 216.32 & $1883-13-2$ & Fatty acid \\
\hline 2 & 25.38 & 3741161 & 0.87 & Lycopersene & $\mathrm{C}_{40} \mathrm{H}_{66}$ & 547 & $502-62-5$ & acyclic carotene \\
\hline 3 & 6.532 & 3687989 & 0.86 & Valeric acid & $\mathrm{C}_{5} \mathrm{H}_{10} \mathrm{O}_{2}$ & 102.13 & $109-52-4$ & saturated fatty acid \\
\hline 4 & 17.099 & 2928528 & 0.688017846 & Isopropyl palmitate & $\mathrm{C}_{19} \mathrm{H}_{38} \mathrm{O}_{2}$ & 298.5 & $142-91-6$ & \\
\hline 5 & 20.00 & 2876594 & 0.67 & Ethyl arachidonate & $\mathrm{C}_{22} \mathrm{H}_{36} \mathrm{O}_{2}$ & 332.5 & $1808-26-0$ & fatty acid ethyl ester \\
\hline 6 & 11.56 & 2485142 & 0.58 & 1-Ethylidene-1H-indene & $\mathrm{C}_{11} \mathrm{H}_{10}$ & 142.2 & $2471-83-2$ & \\
\hline 7 & 18.63 & 1777880 & 0.41 & 13-Heptadecyn-1-Ol & $\mathrm{C}_{17} \mathrm{H}_{32} \mathrm{O}$ & 252.4 & $56554-77-9$ & \\
\hline 8 & 15.647 & 1580754 & 0.37 & Dodecanoic acid,1-methylethyl ester & $\mathrm{C}_{15} \mathrm{H}_{30} \mathrm{O}_{2}$ & 242 & $10233-13-3$ & $\begin{array}{l}\text { fatty acid ester and } \\
\text { an isopropyl ester }\end{array}$ \\
\hline 9 & 18.9 & 1420852 & 0.33 & Ethyl linoleate & $\mathrm{C}_{20} \mathrm{H}_{36} \mathrm{O}_{2}$ & 308.5 & $544-35-4$ & fatty acid ethyl ester \\
\hline 10 & 18.598 & 1369414 & 0.32 & 1-Monolinolenoyl-rac-glycerol & $\mathrm{C}_{21} \mathrm{H}_{36} \mathrm{O}_{4}$ & 352.5 & $18465-99-1$ & \\
\hline 11 & 18.23 & 1071873 & 0.25 & 13-Heptadecyn-1-ol & $\mathrm{C}_{17} \mathrm{H}_{32} \mathrm{O}$ & 252.4 & $56554-77-9$ & \\
\hline 12 & 10.47 & 1000281 & 0.23 & 5-Hydroxymethylfurfural & $\mathrm{C}_{6} \mathrm{H}_{6} \mathrm{O}_{3}$ & 126.11 & $67-47-0$ & furan \\
\hline 13 & 16.47 & 907653 & 0.21 & Geranyl isovalerate & $\mathrm{C}_{15} \mathrm{H}_{26} \mathrm{O}_{2}$ & 238.3 & $109-20-6$ & \\
\hline 14 & 7.41 & 870297 & 0.20446445 & 2-Ethylhexyl trichloroacetate & $\mathrm{C}_{10} \mathrm{H}_{17} \mathrm{Cl}_{3} \mathrm{O}_{2}$ & 275.6 & $16397-79-8$ & \\
\hline 15 & 8.06 & 824996 & 0.19 & 4-Chlorobutyrophenone & $\mathrm{C}_{10} \mathrm{H}_{11} \mathrm{ClO}$ & 182.64 & $939-52-6$ & \\
\hline 16 & 7.39 & 787620 & 0.18 & P-Cymene & $\mathrm{C}_{10} \mathrm{H}_{14}$ & 134.22 & $99-87-6$ & \\
\hline 17 & 10.79 & 684364 & 0.16 & 1-Phenoxy-2-propanol & $\mathrm{C}_{9} \mathrm{H}_{12} \mathrm{O}_{2}$ & 152.19 & $770-35-4$ & \\
\hline 18 & 14.20 & 550520 & 0.12 & $\begin{array}{l}\text { Piperidine-4-carboxylic acid, 1-[2-methyl-2,3- } \\
\text { dihydroindol-1-yl)-2-oxoethyl)-, amide }\end{array}$ & $\mathrm{C}_{17} \mathrm{H}_{23} \mathrm{~N}_{3} \mathrm{O}_{2}$ & 301 & - & \\
\hline 19 & 8.79 & 477712 & 0.11 & 2-Ethylhexanoic acid & $\mathrm{C}_{8} \mathrm{H}_{16} \mathrm{O}_{2}$ & 144.21 & $149-57-5$ & \\
\hline 20 & 11.80 & 455883 & 0.10 & Bicyclo[4.4.1]undeca-1,3,5,7,9-pentaene & $\mathrm{C}_{11} \mathrm{H}_{10}$ & 142.2 & $2443-46-1$ & \\
\hline 21 & 14.67 & 452629 & 0.10 & $\begin{array}{c}\text { Octahydrobenzo(b)pyran, } 4 \mathrm{a} \text {-acetoxy-5,5,8 } \\
\text { a-trimethyl- }\end{array}$ & $\mathrm{C}_{14} \mathrm{H}_{24} \mathrm{O}_{3}$ & 240 & $54344-83-1$ & \\
\hline 22 & 6.60 & 400001 & 0.09 & Phenyl beta-D-glucopyranoside & $\mathrm{C}_{12} \mathrm{H}_{16} \mathrm{O}_{6}$ & 256.25 & $1464-44-4$ & \\
\hline 23 & 26.323 & 338854 & 0.07 & Lycopersene & $\mathrm{C}_{40} \mathrm{H}_{66}$ & 547 & $502-62-5$ & \\
\hline
\end{tabular}

unsaturated alcohols, alkynes etc. were found to be the dominant components and these are known for their positive biological functions. Neophytadiene , 2-Pyrrolidinone, 1-methyl- , Methyl tetradecanoate, Doconexent and Azulene were the major phytocomponents exhibiting bioactivity. The Neophytadiene shows antioxidant, analgesic antipyretic, anti-inflammatory, antimicrobial, antidiabetic, anti-inflamatoty, antiarthritic and anti-cancer activity. 2-Pyrrolidinone, 1-methyl- exhibits immunomodulatory activity and known as antimyeloma compound. Methyl tetradecanoate is being used as a flavouring and fragrancing agent. Doconexent with mixture of other oil act as a very good supplement of DHA (which have anti inflammatory effect in brain). Azulene- acts as a volatile oil component. Data taken together reflects that methanolic extract of $S$. triplicata proves to be a good repository of phytochemicals that holds a great promise in the treatment of cancer in future. However, further in depth studies need to be performed to fully discover its anticancer properties by looking at the different cell signaling pathways linked with cancer development.

\section{AUTHORS CONTRIBUTION}

Ankita Mridha performed all assays and data collection. Priya K Gopal maintained the cell culture. Santanu Paul made over all data analysis and assessment of manuscript.

\section{ACKNOWLEDGEMENTS}

The authors are grateful to Indian Council of Medical Research for their funding, ICMR SRF. Authors are thankful to IISER Earth Science, Kolkata for GC-MS analysis.

\section{CONFLICTS OF INTEREST}

There are no conflicts of interest.

\section{REFERENCES}

1. Ferlay J, Soerjomataram I, Ervik M, Dikshit R, Eser S, Mathers C, et al. Cancer incidence and mortality worldwide: GLOBOCAN 2012. Int J Cancer. 2015;136(5):359-86. 
2. Bray F, Ferlay J, Soerjomataram I, Siegel RL, Torre LA, Jemal A. Global cancer statistics 2018: GLOBOCAN estimates of incidence and mortality worldwide for 36 cancers in 185 countries. CA Cancer J Clin. 2018;68(6):394-424.

3. Arruebo M, Vilaboa N, Gutierrez BS, Lambea J, Tres V, Valladares M, et al. Assessment of the Evolution of Cancer Treatment Therapies. Cancers (Basel). 2011;3(3):3279-330

4. Watkins CL, Fernandez-Robles C, Miller RN, Pine A, Stern Prim TA. Use of Complementary and Alternative Medicine by Patients with Cancer. Care Companion CNS Disord. 2011;13(2):pii: PCC.

5. Wang H, KhorTO, Shu L, Su Z, Fuentes F, Lee JH, et al. Plants Against Cancer: A Review on Natural Phytochemicals in Preventing and Treating Cancers and Their Druggability. Anticancer Agents Med Chem. 2012;12(10):1281-305.

6. Mridha A, Paul S. Algae as potential repository of anticancerous natural compounds. International Journal of Phytomedicine. 2017;9(2017):181-94.

7. Chakraborty T, Pal Basak A, Mridha A, Gopal PK, Paul S. Anti-cancer and antioxidant potential of Indian carpet weed Glinus oppositifolius (L.) Aug. DC. J Pharmacogn Phytochem. 2017;6(5):464-8.

8. Hajra D, Paul S. Study of glucose uptake enhancing potential of fenugreek (Trigonella foenum graecum) leaves extract on 3T3 L1 cells line and evaluation of its antioxidant potential. Phcog Res. 2018;10(4):347-53.

9. Chouni A, Paul S. A Review on Phytochemical and Pharmacological Potential of Alpinia galangal. Pharmacogn J. 2018;10(1):09-15.

10. Dandapat M, Paul S. Secondary metabolites from lichen Usnea longissima and its pharmacological relevance. Phcog Res. 2019;11(2):103-9.

11. Pal A, Chouni A, Das A, Ray R, Paul S. Evaluation of Anti-proliferative Potential and Antioxidant Activity of a Wild Edible Mushroom Macrocybe crassa (Sacc.) Pegler and Lodge. Pharmacognosy Journal. 2019;11(6s):1504-10

12. Correia-da-Silva M, Sousa E, Pinto MM, Kijjoa A. Anticancer and cancer preventive compounds from edible marine organisms. Semin Cancer Biol. 2017;46:55-64.

13. Mridha A, Nandi C, Pal R, Paul S. Studies on few fresh water green algal species reveals Spirogyra triplicata as the repository of high phenolic and flavonoid content exhibiting enhanced anti-oxidant property. J Pharmacogn Phytochem. 6(4):1291-7.

14. Faroogi AA, Butt G, Razzaq Z. Algae extracts and methyl jasmonate anti-cancer activities in prostate cancer: choreographers of 'the dance macabre. Cancer Cell Int. 2012;12:50.
15. Posevitz-Fejfar A, Posevitz V, Gross CC, Bhatia U, Kurth F, Schütte V, et al Effects of blood transportation on human peripheral mononuclear cell yield, phenotype and function: Implications for immune cell biobanking. PLoS One. 2014;9(12):e115920.

16. Gopal PK, Paul M, Paul S. Curcumin Induces Caspase Mediated Apoptosis in JURKAT Cells by Disrupting the Redox Balance. Asian Pac J Cancer Prev. 2014;15(1):93-100.

17. Sarkar S, Gopal PK, Paul S, Andrographolide Induced Apoptosis in NALM6 Cells Mediated Through the Cell Cycle Arrest and Nuclear Fragmentation. Pharmacogn J. 2018;10(2):210-4.

18. Riccardi C, Nicoletti I. Analysis of apoptosis by propidium iodide staining and flow cytometry. Nat Protoc. 2006;1(3):1458-61.

19. Kumar J, Dhar P Tayade AB, Gupta D, Chaurasia OP, Upreti DK, et al. Chemica Composition and Biological Activities of Trans-Himalayan Alga Spirogyra porticalis (Muell.) Cleve. PLoS ONE. 2015;10(2):e0118255

20. pubchem.ncbi.nIm.nih.gov, U.S. National Library of medicine. Ethyl linoleate. [Cited 2020 Jan 20] Available from: https://pubchem.ncbi.nlm.nih.gov/ compound/Ethyl-linoleate

21. Swamy MK, Arumugam G, Kaur R, Ghasemzadeh A, Yusoff MM, Sinniah UR GC-MS Based Metabolite Profiling, Antioxidant and Antimicrobial Properties of Different Solvent Extracts of Malaysian Plectranthus amboinicus Leaves. Evid Based Complement Alternat Med. 2017;1517683.

22. arkema.com. Hexylene-glycol. General statement. [Cited 2020 Jan 20] Available from:https:/www.arkema com/export/shared/.content/media/ downloads/socialresponsability/safety-summuries/Thiochemicals-hexyleneglycol-2012-04-30.pdf

23. drugbank.ca. Doconexent.[ Cited 2020 Jan 20] Available from: http://www. drugbank.ca/drugs/DB03756

24. ebi.ac.uk. [ Cited 2019 Nov 4] Available from: http://www.ebi.ac.uk/chebi/ searchld.do?chebild=CHEBI:31249)

25. ebi.ac.uk. [ Cited 2019 Nov 4] Available from: http://www.ebi.ac.uk/chebi/ searchld.do?chebild=CHEBI:35459)

26. vpharmachem.com. Solvents. [ Cited 2019 Nov 4] Available from: https:// vpharmachem.com/solvents

27. Shortt J, Hsu AK, Martin BP, Doggett K, Matthews GM, Doyle MA et al. The drug vehicle and solvent $\mathrm{N}$-methylpyrrolidone is an immunomodulator and antimyeloma compound. Cell Rep. 2014;7(4):1009-19.

28. ebi.ac.uk. [Cited 2019 Nov 4] Available from: https://www.ebi.ac.uk/chebi/ searchld.do?chebild=CHEBI:89199)

\section{GRAPHICAL ABSTRACT}

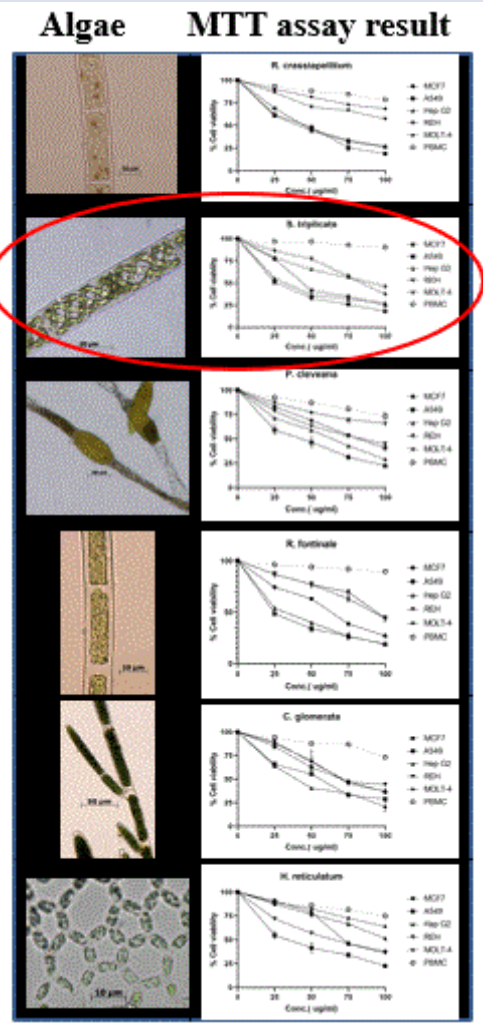

Best

Result
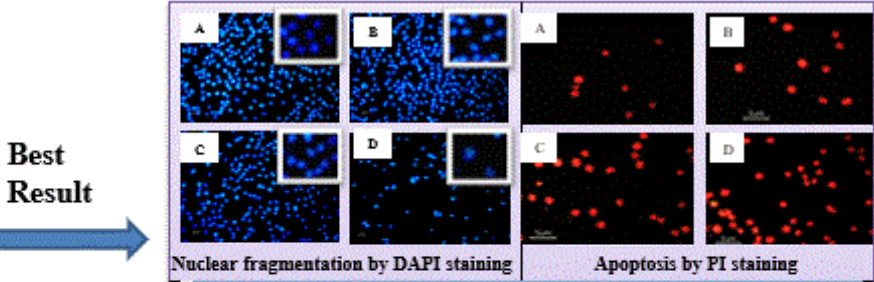

uclear fragmentation by DAPI stainin

Apoptosis by PI staining

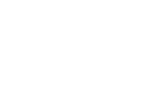

Major

Components
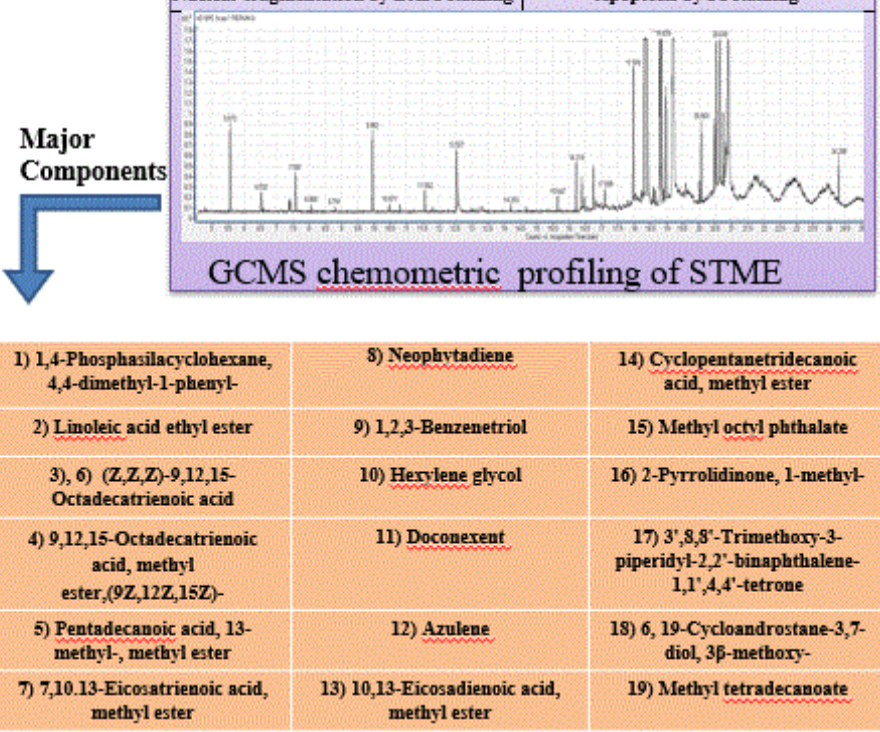

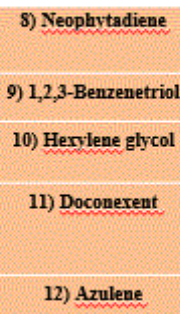

13) 10,13-Eicosadienoic acid methyl ester

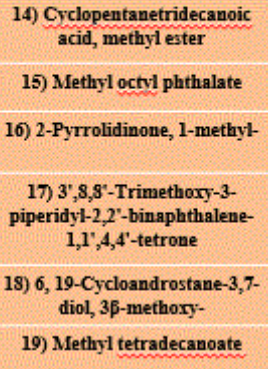
15) Methyl octvi phthalat

17) 3 ', 8, 8'-Trimethoxy-3. dyl-2,2'-binaphthalen 19-Cycloandrostane-3,719) Methyl tetradecanoate 


\section{ABOUT AUTHORS}

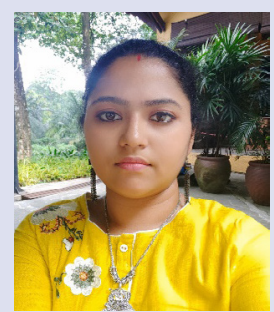

Ankita Mridha is a Senior Research Fellow funded by Indian Council of Medical Research at the Department of Botany, University of Calcutta, India.

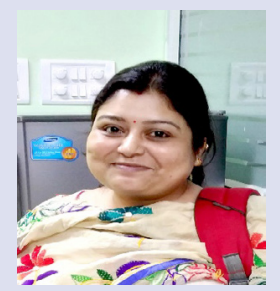

Dr. Priya K Gopal is currently an Assistant Professor of Microbiology at the Muralidhar Girls College, Kolkata, India and has done her PhD under the supervision of Dr. Santanu Paul.

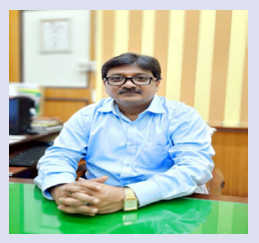

Dr. Santanu Paul is a Professor of Botany, University of Calcutta, India and also the chief of the "Laboratory of Cell and Molecular Biology." Has immense knowledge and experience in the molecular mechanism of apoptosis induction in cancer cells induced by compounds from plants.

Cite this article: Mridha A, Gopal PK, Paul S. Screening Data Reveals that Spirogyra triplicata, a Fresh Water Algae Induces Robust Anti-Proliferative Activity Against A549 Cells. Pharmacogn J. 2020;12(3):569-77. 